\title{
Alterations of the $\mathrm{Ca}^{2+}$ signaling pathway in pancreatic beta-cells isolated from $\mathrm{db} / \mathrm{db}$ mice
}

\author{
Kuo Liang ${ }^{1}$, Wen $\mathrm{Du}^{2}$, Jingze $\mathrm{Lu}^{2}$, Fei $\mathrm{Li}^{1 凶}$, Lu Yang ${ }^{3}$, Yanhong Xue ${ }^{2}$, Bertil Hille ${ }^{4}$, Liangyi Chen ${ }^{3 \bowtie}$ \\ ${ }^{1}$ Department of General Surgery, XuanWu Hospital, Capital Medical University, Beijing 100053, China \\ 2 National Key Laboratory of Biomacromolecules, Institute of Biophysics, Chinese Academy of Science, Beijing 100101, China \\ ${ }^{3}$ The State Key Laboratory of Biomembrane and Membrane Biotechnology, Beijing Key Laboratory of Cardiometabolic \\ Molecular Medicine, Institute of Molecular Medicine, Peking University, Beijing 100871, China \\ ${ }^{4}$ Department of Physiology and Biophysics, University of Washington School of Medicine, Seattle, WA 98195, USA \\ $\square$ Correspondence: Iychen@pku.edu.cn (L. Chen), feili36@ccmu.edu.cn (F. Li) \\ Received January 22, 2014 Accepted April 20, 2014
}

\begin{abstract}
Upon glucose elevation, pancreatic beta-cells secrete insulin in a $\mathrm{Ca}^{2+}$-dependent manner. In diabetic animal models, different aspects of the calcium signaling pathway in beta-cells are altered, but there is no consensus regarding their relative contributions to the development of beta-cell dysfunction. In this study, we compared the increase in cytosolic $\mathrm{Ca}^{2+}\left(\left[\mathrm{Ca}^{2+}\right]_{i}\right)$ via $\mathrm{Ca}^{2+}$ influx, $\mathrm{Ca}^{2+}$ mobilization from endoplasmic reticulum (ER) calcium stores, and the removal of $\mathrm{Ca}^{2+}$ via multiple mechanisms in beta-cells from both diabetic $\mathrm{db} / \mathrm{db}$ mice and nondiabetic C57BL/6J mice. We refined our previous quantitative model to describe the slow $\left[\mathrm{Ca}^{2+}\right]_{\mathrm{i}}$ recovery after depolarization in beta-cells from $\mathrm{db} / \mathrm{db}$ mice. According to the model, the activity levels of the two subtypes of the sarco-endoplasmic reticulum $\mathrm{Ca}^{2+}$-ATPase (SERCA) pump, SERCA2 and SERCA3, were severely down-regulated in diabetic cells to $65 \%$ and $0 \%$ of the levels in normal cells. This down-regulation may lead to a reduction in the $\mathrm{Ca}^{2+}$ concentration in the ER, a compensatory up-regulation of the plasma membrane $\mathrm{Na}^{+} / \mathrm{Ca}^{2+}$ exchanger (NCX) and a reduction in depolarizationevoked $\mathrm{Ca}^{2+}$ influx. As a result, the patterns of glucosestimulated calcium oscillations were significantly different in $\mathrm{db} / \mathrm{db}$ diabetic beta-cells compared with normal
\end{abstract}

Kuo Liang, Wen Du, Jingze Lu have contributed equally to this work.

Electronic supplementary material The online version of this article (doi:10.1007/s13238-014-0075-7) contains supplementary material, which is available to authorized users. cells. Overall, quantifying the changes in the calcium signaling pathway in $\mathrm{db} / \mathrm{db}$ diabetic beta-cells will aid in the development of a disease model that could provide insight into the adaptive transformations of beta-cell function during diabetes development.

KEYWORDS diabetic beta-cells, calcium signaling alterations, SERCA pump, db/db mice

\section{INTRODUCTION}

Diabetes affects millions of people and exacts a significant toll on both individual health and society as a whole. Because diabetes is associated with both genetic and environmental factors, the etiology of the disease is complicated and unclear. Interestingly, different $\mathrm{Ca}^{2+}$ signaling components are disturbed in a wide range of organelles in diabetic animals and patients, suggesting a pivotal role for the dysregulation of $\mathrm{Ca}^{2+}$ signaling in the development of diabetes (Bergsten 2000).

Upon blood glucose elevation, pancreatic beta-cells secrete insulin in an intracellular $\mathrm{Ca}^{2+}$ concentration $\left(\left[\mathrm{Ca}^{2+}\right]_{\mathrm{i}}\right)-$ dependent manner, which acts on downstream target tissues to facilitate glucose uptake. This process involves different components of the $\mathrm{Ca}^{2+}$ signaling pathways. For example, depolarization triggered by glucose metabolism opens L-type voltage-gated $\mathrm{Ca}^{2+}$ channels, leading to an initial extracellular $\mathrm{Ca}^{2+}$ influx (Rorsman 1997) and the subsequent mobilization of $\mathrm{Ca}^{2+}$ stores via pathways such as the $\mathrm{IP}_{3}$ and ryanodine receptors (Islam 2002; Duman et al. 2006). Simultaneously, clearance mechanisms such as the 
sarco/endoplasmic reticulum $\mathrm{Ca}^{2+}$-ATPase (SERCA), the plasma membrane $\mathrm{Ca}^{2+}$-ATPase (PMCA) and the sodium calcium exchanger (NCX) are activated to reduce elevated $\left[\mathrm{Ca}^{2+}\right]_{\mathrm{i}}$ to the physiological resting level (Chen et al. 2003; Hughes et al. 2006). Altered $\mathrm{Ca}^{2+}$ signaling is consistently observed in pancreatic beta-cells in diabetic animal models. For example, the L-type calcium channel was up-regulated in both neonatally streptozocin-induced and Goto-Kakizaki (GK) diabetic rats (Kato et al. 1996; Kato et al. 1994) but was down-regulated in islets from other rat models of type II diabetes (Iwashima et al. 2001; Roe et al. 1996). An altered release of endoplasmic reticulum (ER) $\mathrm{Ca}^{2+}$ stores via the ryanodine receptor has also been hypothesized to occur during diabetes development (Islam 2002).

SERCA is the major $\mathrm{Ca}^{2+}$ extrusion mechanism in mouse and rat pancreatic beta-cells (Chen et al. 2003; Hughes et al. 2006). SERCA pump activity could not be detected in $\mathrm{db} / \mathrm{db}$ islets (Roe et al. 1994), whereas a selective down-regulation of SERCA3 sub-type mRNA has been reported in GK rats (Varadi et al. 1996). Missense mutations in human SERCA3 have been associated with type II diabetes (Varadi et al. 1999), suggesting a crucial role for SERCA3 in the etiology of diabetes. However, SERCA3-specific knockout (KO) mice are normoglycemic and have normal insulinemia (Arredouani et al. 2002). PMCA activity is down-regulated in certain types of diabetic islets (Roe et al. 1994; Hoenig et al. 1990; Levy et al. 1998), in contrast to beta-cells cultured under high glucose conditions, which exhibited enhanced NCX transcription (Ximenes et al. 2003). These controversies can only be resolved if the functions of different $\mathrm{Ca}^{2+}$ signaling proteins in normal and diabetic beta-cells are systematically compared under identical experimental conditions.

To address these questions, we compared calcium clearance in age-matched pancreatic beta-cells that were isolated from both C57BL/6J control mice and $\mathrm{db} / \mathrm{db}$ mice, a widely used type II diabetic mouse model. The changes can be quantitatively modeled as a $35 \%$ reduction in SERCA2 activity, a full inhibition of the SERCA3 pump, a $30 \%$ increase in the NCX capacity and a $27 \%$ reduction in $\mathrm{Ca}^{2+}$ influx. Despite the severely compromised SERCA function, the $\mathrm{Ca}^{2+}$ concentration in the $\mathrm{ER}\left(\left[\mathrm{Ca}^{2+}\right]_{E R}\right)$ was reduced only slightly, to $89 \%$ of the control, while the ER mobilization pathways remained unchanged. Overall, these changes led to significant alterations in the glucose-induced calcium oscillations in the beta-cells of the $\mathrm{db} / \mathrm{db}$ mice relative to the control.

\section{RESULTS}

$\mathrm{Ca}^{2+}$ clearance after depolarization stimulated $\mathrm{Ca}^{2+}$ influx in normal and $\mathrm{db} / \mathrm{db}$ beta-cells

We have previously dissected the contributions of multiple clearance mechanisms in pancreatic beta-cells isolated from Balb/c mice through pharmacological manipulation (Chen et al. 2003). In this work, we used this method to compare the clearance mechanisms in beta-cells isolated from agematched $\mathrm{db} / \mathrm{db}$ and C57BL/6J mice. To quantitatively evaluate $\mathrm{Ca}^{2+}$ clearance after depolarization, control and $\mathrm{db} / \mathrm{db}$ cells were stimulated with $70 \mathrm{mmol} / \mathrm{L} \mathrm{KCl}$ for $3 \mathrm{~s}$ and then switched to normal extracellular solution (Fig. $1 \mathrm{~A}$ and $1 \mathrm{~B}$ ). Compared with normal beta-cells, the $\mathrm{db} / \mathrm{db}$ cells exhibited a reduced depolarization-triggered $\left[\mathrm{Ca}^{2+}\right]_{i}$ elevation, and $\left[\mathrm{Ca}^{2+}\right]_{i}$ returned to the basal level in normal extracellular solution at a significantly slower rate. In cells that had been pre-treated with thapsigargin (TG), an irreversible inhibitor of the SERCA pump, the increase in $\left[\mathrm{Ca}^{2+}\right]_{i}$ remained smaller, but the clearance was faster in $\mathrm{db} / \mathrm{db}$ cells than it was in the control cells (Fig. 1C and 1D). This result suggested not only an impairment of the SERCA pump but also a possible up-regulation of clearance mechanisms other than the SERCA pump in $\mathrm{db} / \mathrm{db}$ beta-cells. To dissect the contributions of NCX and PMCA in clearance, we switched to a $\mathrm{Na}^{+}$-free solution (Li7.4) or a high pH extracellular solution (Na8.8) after depolarization in cells pretreated with TG (Chen et al. 2003). Compared with the control cells, $\mathrm{Ca}^{2+}$ clearance in $\mathrm{db} / \mathrm{db}$ cells was much faster in the presence of SERCA and PMCA inhibition ( $\mathrm{TG}+\mathrm{Na8} .8)$. In contrast, $\left[\mathrm{Ca}^{2+}\right]_{i}$ returned to the basal level with the same kinetics in $\mathrm{db} / \mathrm{db}$ and control cells when only the PMCA pump was functioning (TG + Li7.4). Taken together, these results indicate the selective downregulation of depolarization-induced $\mathrm{Ca}^{2+}$ influx and the SERCA pump and the up-regulation of NCX in $\mathrm{db} / \mathrm{db}$ cells.

\section{Reduced function of the SERCA pump in $\mathrm{db} / \mathrm{db}$ beta- cells compared with the control}

The relative expression levels of the SERCA pump in normal and $\mathrm{db} / \mathrm{db}$ islets were studied using a SERCA-specific antibody that recognizes all three isoforms of SERCA. In agreement with previous experiments (Roe et al. 1994; Varadi et al. 1996), the SERCA protein levels were severely reduced in $\mathrm{db} / \mathrm{db}$ islets compared with normal islets (Fig. 2A). Because the Western blotting experiments were performed using whole islets that contain alpha- and betacells, it is difficult to determine the specific reduction in SERCA in beta-cells. Therefore, we took a direct approach to measure SERCA function in live beta-cells (Duman et al. 2006; Albrecht et al. 2002). The application of a high concentration of a rapid inhibitor of the SERCA pump, BHQ (100 $\mu \mathrm{mol} / \mathrm{L}$ ), in resting cells (Fig. $2 \mathrm{~B}$ ) or in cells that were stimulated with a short ( $3 \mathrm{~s}$, Fig. $2 \mathrm{C}$ ) or long (30 s, Fig. 2D) depolarization, produced an upstroke in the $\left[\mathrm{Ca}^{2+}\right]_{i}$ trace. The difference between the BHQ-induced rate of change in $\left[\mathrm{Ca}^{2+}\right]_{i}\left(\mathrm{~J}_{2}\right)$ and the initial slope of the $\left[\mathrm{Ca}^{2+}\right]_{i}$ trace immediately before BHQ application $\left(J_{1}\right)$ represented the SERCAdependent uptake of cytosolic $\mathrm{Ca}^{2+}$, which was correlated with different $\left[\mathrm{Ca}^{2+}\right]_{i}$ levels (Duman et al. 2006; Albrecht et al. 2002). SERCA activity was inhibited at $\left[\mathrm{Ca}^{2+}\right]_{\mathrm{i}}$ ranging from $200 \mathrm{~nm}$ to $1000 \mathrm{~nm}$, with increased inhibition at higher $\left[\mathrm{Ca}^{2+}\right]_{\mathrm{i}}$ (Fig. 2D). 

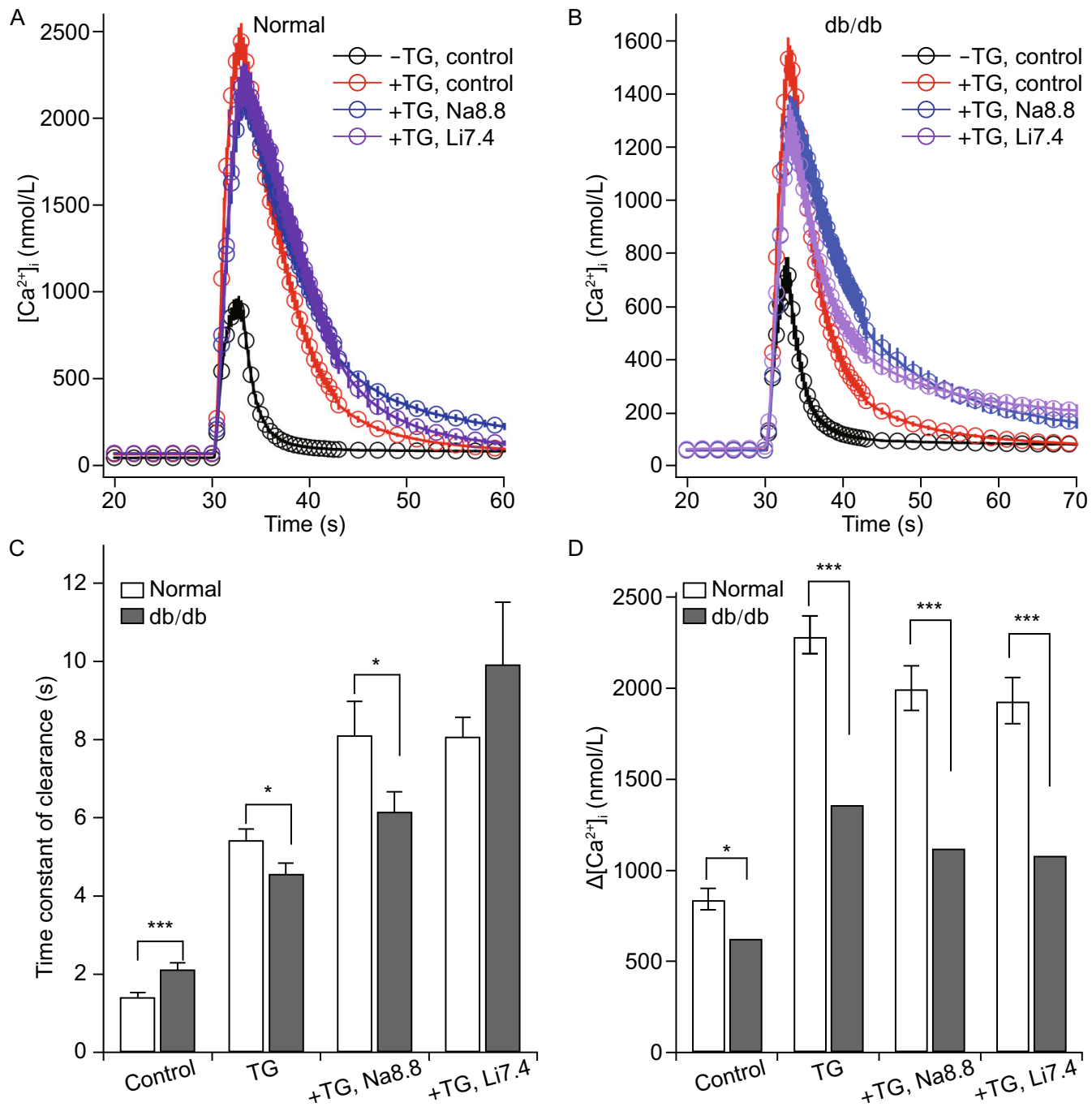

Figure 1. $\mathrm{Ca}^{2+}$ recoveries after short depolarizations in normal and $\mathrm{db} / \mathrm{db}$ diabetic beta-cells. (A) Averaged clearances in normal beta-cells pretreated with $1 \mu \mathrm{mol} / \mathrm{L} \mathrm{TG}$ in control solution ( $n=42$, red), Li7.4 solution $(n=21$, blue) and Na8.8 solution ( $n=22$, purple) and in cells that were not pretreated with TG $(n=25$, dark). (B) Averaged clearances in db/db beta-cells pretreated with $1 \mu \mathrm{mol} / \mathrm{L} \mathrm{TG}$ in control solution ( $n=32$, red), Li7.4 solution $(n=16$, blue) and Na8.8 solution ( $n=16$, purple) and in cells that were not pretreated with TG $(n=34$, dark). (C) Summary of the recovery time constants in different solutions from normal and db/db beta-cells.

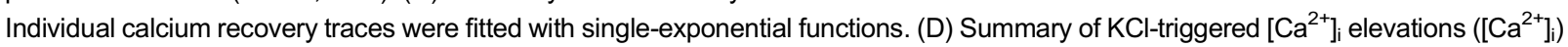
in different solutions from normal and $\mathrm{db} / \mathrm{db}$ beta-cells.

Quantitative modeling of the alterations in $\mathrm{Ca}^{2+}$ influx and clearance in $\mathrm{db} / \mathrm{db}$ beta-cells

Previously, we built a mathematical model to simulate calcium clearance in normal beta-cells that used the $K_{d}$ for SERCA2 for SERCA in the simulation (Chen et al. 2003). However, pancreatic beta-cells also express the SERCA3 subtype (Varadi et al. 1996), which has a much lower affinity for $\mathrm{Ca}^{2+}(1100 \mathrm{nmol} / \mathrm{L})$ than does SERCA2 $(270 \mathrm{nmol} / \mathrm{L})$ (Lytton et al. 1992). We therefore revised our model to accommodate two SERCA subtypes and manipulated the maximal flux rates through the influx and clearance mechanisms to best simulate the peaks of transient $\left[\mathrm{Ca}^{2+}\right]_{i}$ and the time constants following depolarization in normal cells under different conditions (Fig. 3A). This simulation yielded a $V_{\text {max }}$ SERCA2: $\vee$ max $_{\text {SERCA3 } 3}$ ratio of approximately 1.2:1, and the total SERCA activity correlated well with the experimental data throughout a wide range of $\left[\mathrm{Ca}^{2+}\right]_{i}$ (Fig. 2D, dark dashed lines). By comparing the experimental depolarization-evoked peak $\left[\mathrm{Ca}^{2+}\right]_{i}$ elevations in the control and $\mathrm{db} / \mathrm{db}$ beta-cells pretreated with TG, we determined that a $27 \%$ decrease in $\mathrm{Ca}^{2+}$ influx from $\mathrm{db} / \mathrm{db}$ cells was required to account for the decrease in amplitude triggered by depolarization. Based on the clearance dynamics in normal and $\mathrm{db} / \mathrm{db}$ cells treated with TG + Li7.4 and TG $+\mathrm{Na8.8}$, we 
A
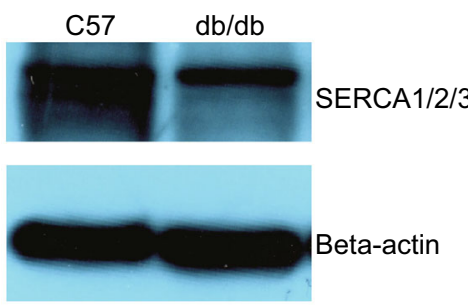

B

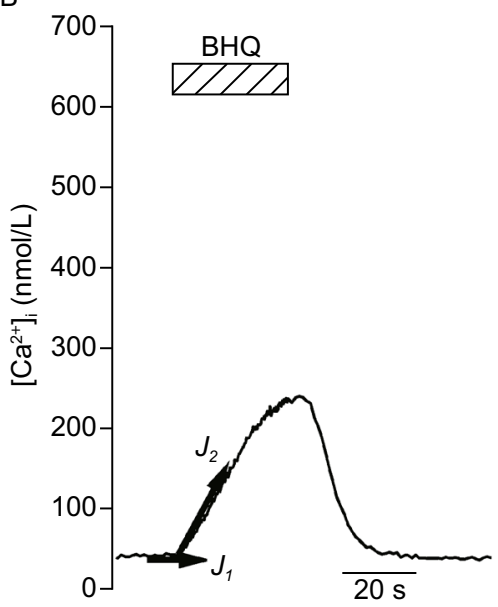

C

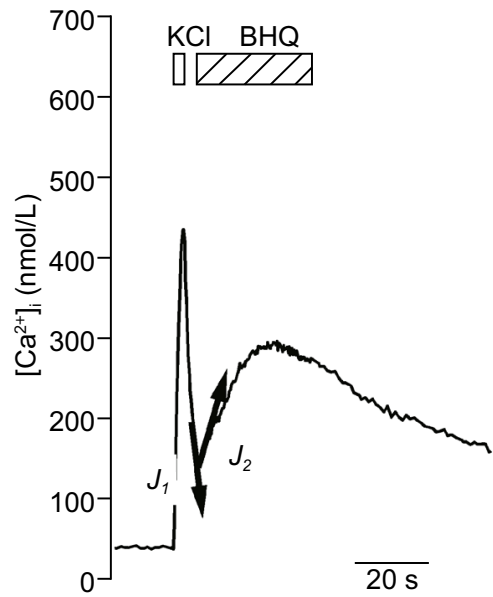

D

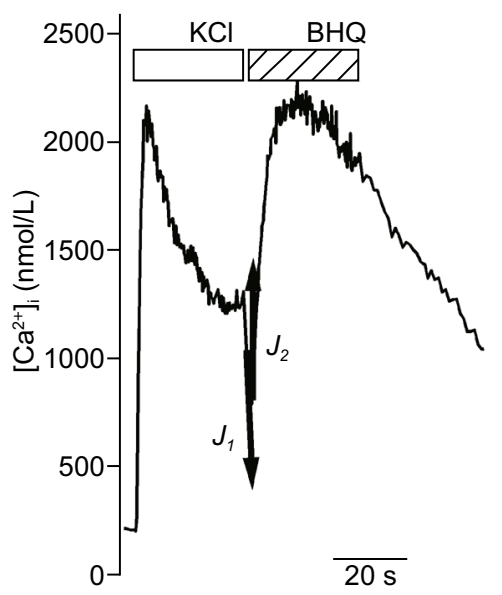

E

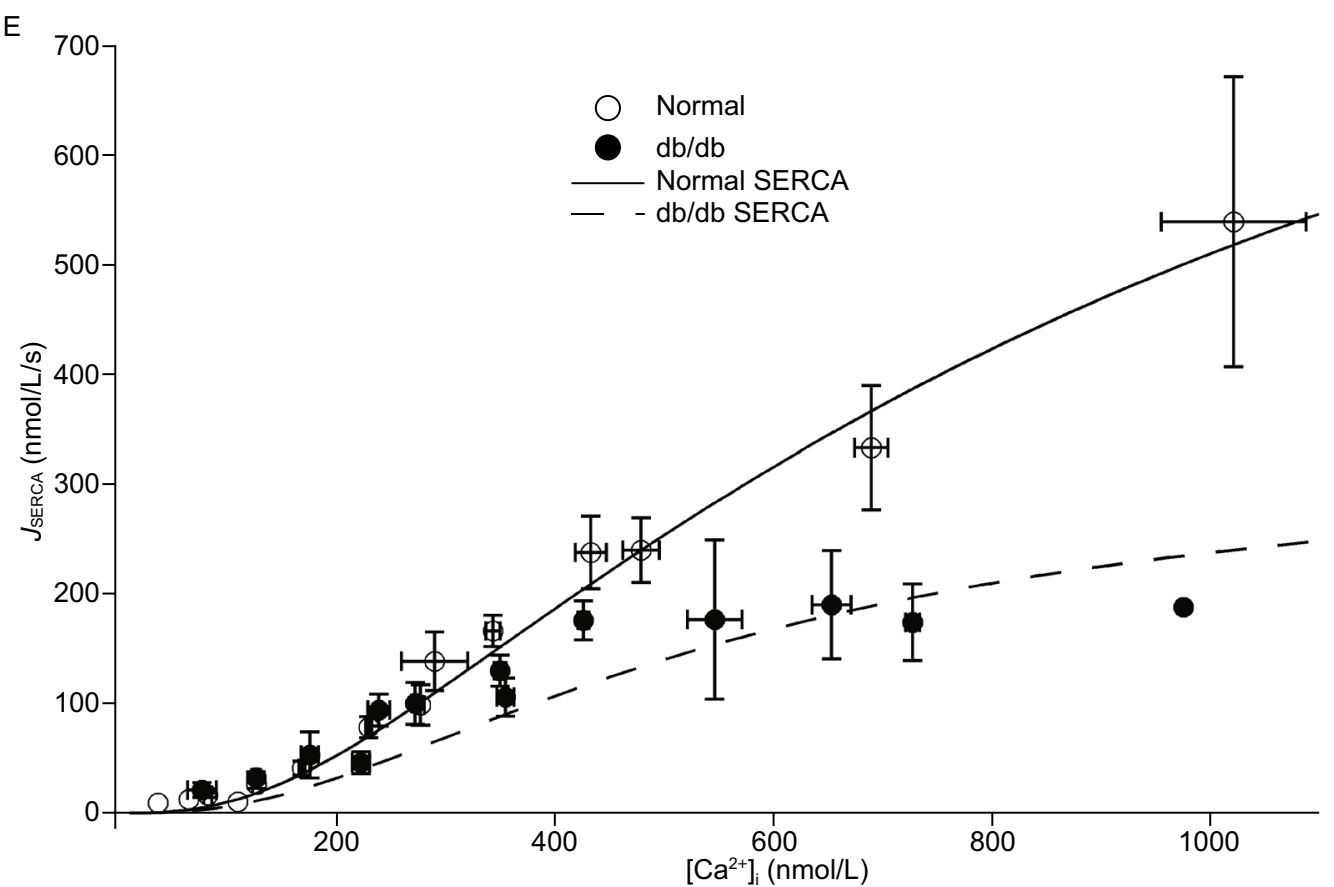

Figure 2. Impaired SERCA function in beta-cells from $\mathrm{db} / \mathrm{db}$ mice. (A) Reduced total SERCA protein levels in islets from $\mathrm{db} / \mathrm{db}$ mice compared to those from normal mice. Beta-actin was used as an internal control, and the figure is representative of three independent repeats. (B-D) BHQ $(100 \mu \mathrm{mol} / \mathrm{L})$ was acutely applied to resting cells $(\mathrm{B})$ and cells that had been previously stimulated with $\mathrm{KCl}$ for $3 \mathrm{~s}(\mathrm{C})$ or $30 \mathrm{~s}(\mathrm{D})$. The total cellular $\mathrm{Ca}^{2+}$ flux (defined as $-\mathrm{d}\left[\mathrm{Ca}^{2+}\right] / / \mathrm{dt}$ ) before $\left(J_{1}\right)$ and after $\left(J_{2}\right)$ BHQ application was plotted on each figure. (E) $J_{S E R C A}$ from normal beta-cells (open circle, $n=256$ ) and from $\mathrm{db} / \mathrm{db}$ diabetic beta-cells (filled circle, $n=119$ ) as a function of $\left[\mathrm{Ca}^{2+}\right]_{i}$. The line indicates the total SERCA activity in normal beta-cells (including both SERCA2 and SERCA3 activity) according to the model, whereas the dashed line represents the activity in $\mathrm{db} / \mathrm{db}$ cells. 
A

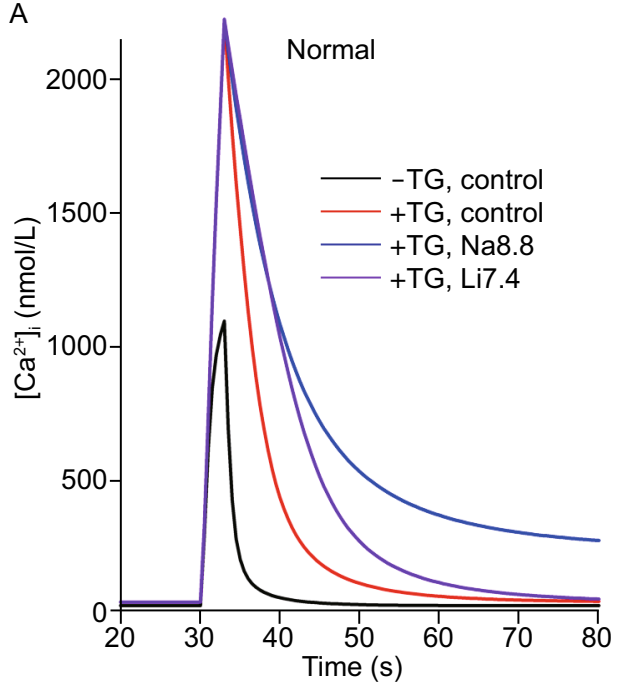

C

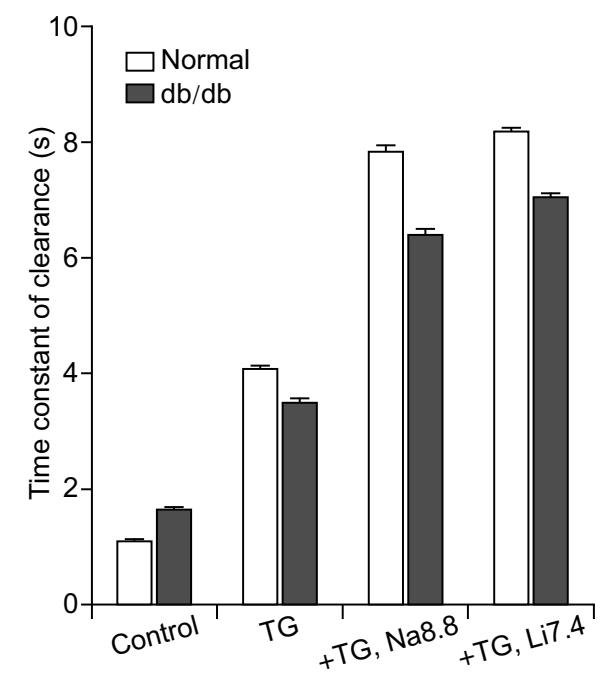

E

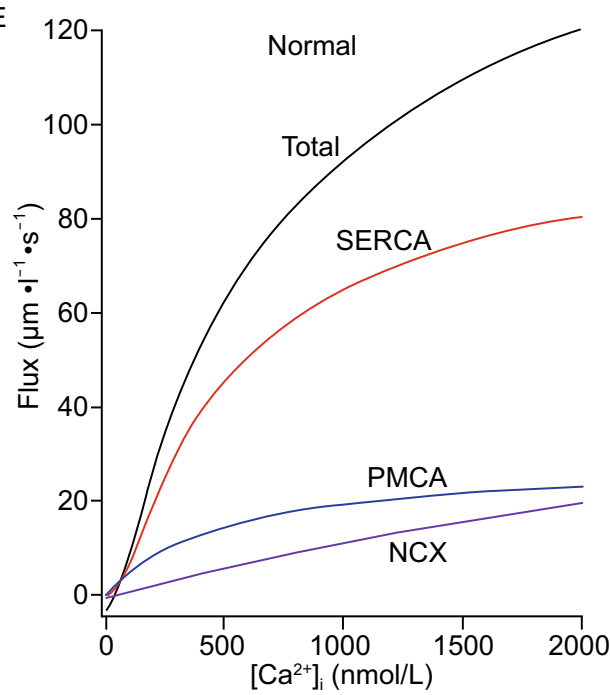

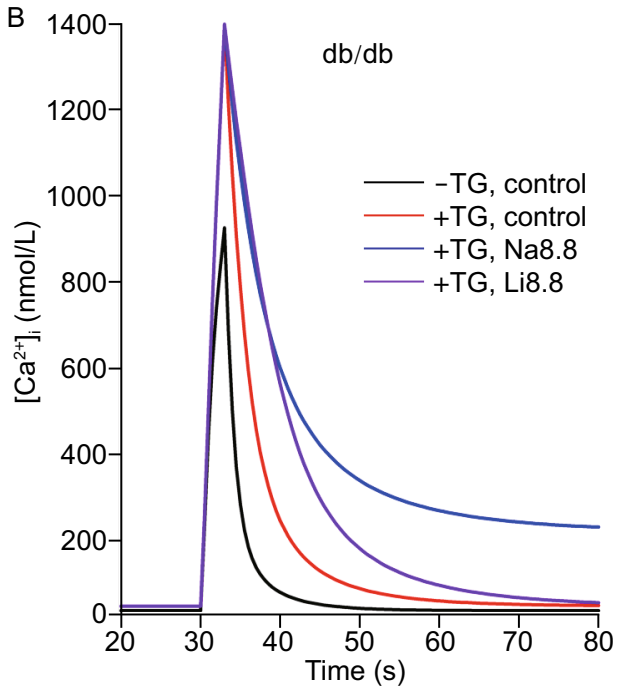

D

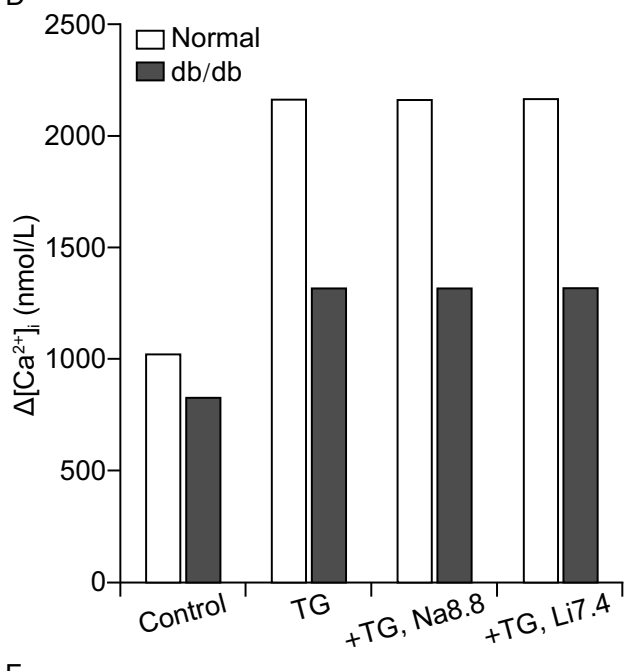

F

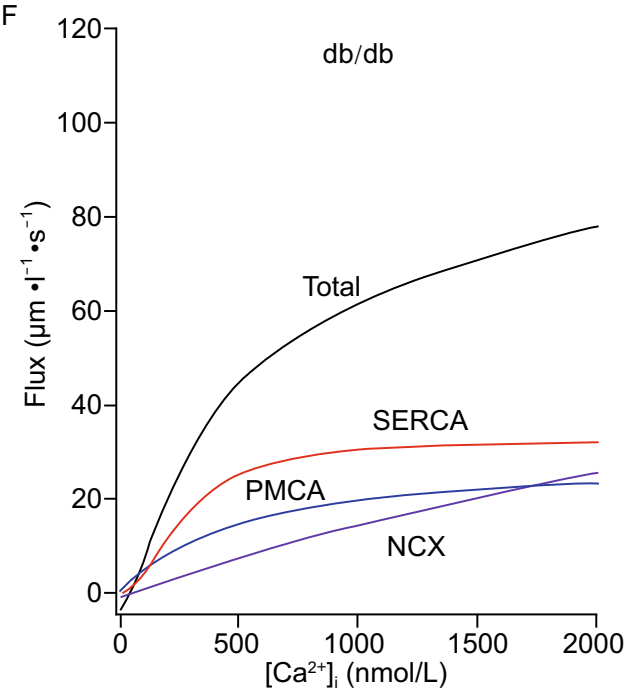


Figure 3. Simulated $\mathrm{Ca}^{2+}$ recoveries after short depolarizations in normal and $\mathrm{db} / \mathrm{db}$ diabetic beta-cells. (A and $B$ ) Simulated clearances under different conditions obtained from normal beta-cells $(A)$ and $\mathrm{db} / \mathrm{db}$ diabetic beta-cells $(B)$. ( $C$ and D) Simulated recovery time constants $(C)$ and $\mathrm{KCl}$-triggered $\left[\mathrm{Ca}^{2+}\right]_{i}$ elevations (D) in beta-cells from normal and $\mathrm{db} / \mathrm{db}$ mice. ( $E$ and $F$ ) Simulated kinetic model for $\mathrm{Ca}^{2+}$ transport in normal $(E)$ and $\mathrm{db} / \mathrm{db}(\mathrm{F})$ beta-cells. The flux rates were much higher than the rates of $\left[\mathrm{Ca}^{2+}\right]_{i}$ change shown in Fig. $2 \mathrm{E}$ because the model includes the effects of strong $\mathrm{Ca}^{2+}$ binding in the cytoplasm by endogenous buffers and fluorescent indicators.

determined that the NCX activity in $\mathrm{db} / \mathrm{db}$ cells was up-regulated $130 \%$ relative to control cells. The residual activity levels of SERCA2 and SERCA3 in $\mathrm{db} / \mathrm{db}$ beta-cells were $65 \%$ and $0 \%$ of their respective levels in the control cells, which approximated the experimental data nicely (Fig. 2D, red dashed line). With these altered parameters, the simulated $\left[\mathrm{Ca}^{2+}\right]_{i}$ elevation and the clearance dynamics after depolarization fit the experimental data relatively well (Fig. 3B-D). With the parameters chosen, we reproduced the relative flux rates of the model for normal and beta-cells from $\mathrm{db} / \mathrm{db}$ mice (Fig. 3E and $3 \mathrm{~F}$ ). The total $\mathrm{Ca}^{2+}$ extrusion rate in $\mathrm{db} / \mathrm{db}$ beta-cells was $\sim 66 \%$ of the control, and the relative role of SERCA was also reduced (from $\sim 66 \%-71 \%$ of the total flux to $\sim 41 \%-56 \%$ ). In contrast, the relative contribution of the NCX increased, especially at high $\left[\mathrm{Ca}^{2+}\right]_{\mathrm{i}}(>900 \mathrm{~nm})$, indicating that NCX hyper-activity may compensate for the loss of the SERCA3 subtype.

No alterations in ER $\mathrm{Ca}^{2+}$ permeability in $\mathrm{db} / \mathrm{db}$ betacells compared to the control

SERCA pump defects combined with an up-regulation of NCX function often result in reduced uptake of $\mathrm{Ca}^{2+}$ to ER calcium stores (Ximenes et al. 2003), and alterations in ER permeability during diabetes have been suggested (Islam 2002). To quantitatively evaluate the $\mathrm{Ca}^{2+}$ content in the ER and its permeability, we modified a protocol from a previous study conducted in sympathetic neurons (Albrecht et al. 2002). Cells were initially bathed in an extracellular solution that did not contain $\mathrm{Ca}^{2+}$ or $\mathrm{Na}^{+}$(Li7.4) to block the NCX and $\mathrm{Ca}^{2+}$ influx and were then perfused with $\mathrm{BHQ}$ to trigger $\mathrm{Ca}^{2+}$ release from the $\mathrm{ER}$ calcium stores (Fig. 4A). After $\left[\mathrm{Ca}^{2+}\right]_{\mathrm{i}}$ returned to the basal level, the cells were depolarized for $3 \mathrm{~s}$ in the presence of $4 \mathrm{mmol} / \mathrm{L} \mathrm{Ca}^{2+}$ to boost the $\mathrm{Ca}^{2+}$ influx. Finally, the extracellular solution was changed back to the $\mathrm{Ca}^{2+}$ - and $\mathrm{Na}^{+}$-free solution with $\mathrm{BHQ}$. The rate of $\mathrm{Ca}^{2+}$ extrusion after $\mathrm{KCl}$ depolarization was therefore due solely to the PMCA $\left(J_{P M C A}\right)$ and could be described by a Hill function that correlated with the different $\left[\mathrm{Ca}^{2+}\right]_{i}$ levels (Fig. 4B). Because the calcium-flux changes induced by the first $B H Q$ application $\left(J_{B H Q}(t)\right)$ were a result of both the release from the $\operatorname{ER}\left(J_{\text {release }}\right)$ and $\mathrm{Ca}^{2+}$ extrusion via the PMCA, the $J_{\text {release }}(\mathrm{t})$ was calculated as the difference between $J_{B H Q}$ and $J_{P M C A}$ at each time point (Fig. 4C). The drop in the $\mathrm{ER} \mathrm{Ca}{ }^{2+}$ concentration $\left(\left[\mathrm{Ca}^{2+}\right]_{E R}\right)$ at different time points was calculated based on the following equation:

$\Delta\left[C a^{2+}\right]_{E R}(t)=-\frac{v_{i}}{v_{E R} K_{E R}} \int_{t}^{\text {end }} J_{\text {release }} K_{i} d t=\frac{v_{i}}{v_{E R} K_{E R}} \Delta\left[C a^{2+}\right]_{E R}^{(i)}(t)$,

(Albrecht et al. 2002), in which $v_{i}$ and $v_{E R}$ are the volumes of the cytoplasm and the ER, respectively, and $K_{i}$ and $K_{E R}$ are the calcium buffering ratios of the cytoplasm and the ER, respectively. The minus of the integral $\left(\Delta\left[\mathrm{Ca}^{2+}\right]_{E R}^{(i)}(t)\right)$ was the change in total cytoplasmic $\mathrm{Ca}^{2+}$ concentration that would occur if from time $t$ onward, $J_{\text {release }}$ were deposited into a closed compartment that has the same volume as the cytoplasm. Assuming that $\left[\mathrm{Ca}^{2+}\right]_{\mathrm{ER}}$ equilibrates with $\left[\mathrm{Ca}^{2+}\right]_{\mathrm{i}}$ after $\mathrm{BHQ}$ application, we calculated the initial content in the ER according to the following equation:

$\Delta\left[\mathrm{Ca}^{2+}\right]_{E R}^{i}(0)=\left[\mathrm{Ca}^{2+}\right]_{i, \text { end }} K_{i}+\int_{0}^{\text {end }} J_{\text {release }} K_{i} d t$

Therefore, the time course of $\Delta\left[\mathrm{Ca}^{2+}\right]_{E R}^{(i)}(t)$ was shown in Fig. 4D, and the relative permeability of the ER was estimated according to the equation

$P_{E R}(t)\left[\frac{v_{i}}{v_{E R} K_{E R}}\right] \approx-\frac{J_{\text {release }}(t)}{\Delta\left[\mathrm{Ca}^{2+}\right]_{E R}^{(i)}(t)}$ (Fig. 4E) (Albrecht et al. 2002).

In beta-cells from $\mathrm{db} / \mathrm{db}$ mice, the BHQ-triggered $\left[\mathrm{Ca}^{2+}\right]_{\mathrm{i}}$ transient was significantly lower than in the control cells (Fig. 5A). Based on the calculations, the average $\left[\mathrm{Ca}^{2+}\right]_{E R}^{i}$ in the $\mathrm{db} / \mathrm{db}$ beta-cells was approximately $89 \%$ of the value in the normal cells (Fig. 5C, $P<0.05$ ). Although the time courses of $J_{\text {release }}$ were apparently different in different cell types (Fig. 5B), the relative permeabilities of the ER were approximately the same (Fig. 5D), suggesting that the difference in $E R$ release was due to a difference in the initial $\left[\mathrm{Ca}^{2+}\right]_{\mathrm{ER}}$.

\section{Glucose-induced calcium oscillations in normal and $\mathrm{db} / \mathrm{db}$ beta-cells}

Finally, we directly monitored the calcium oscillations induced by $15 \mathrm{mmol} / \mathrm{L}$ glucose in normal and $\mathrm{db} / \mathrm{db}$ betacells (Fig. 6A). Upon the application of glucose, $\left[\mathrm{Ca}^{2+}\right]_{i}$ often decreased slightly before being elevated, which was suggested to be due to the ATP-activated SERCA-dependent sequestration of $\left[\mathrm{Ca}^{2+}\right]_{i}$ in the ER (Marie et al. 2001). Consistent with a significant inhibition of SERCA2 activity (Fig. 3), the initial decrease in $\left[\mathrm{Ca}^{2+}\right]_{i}$ was reduced significantly in $\mathrm{db} / \mathrm{db}$ cells (Fig. 6B). The maximal elevation in $\left[\mathrm{Ca}^{2+}\right]_{\mathrm{i}}$ triggered by glucose was also reduced in $\mathrm{db} / \mathrm{db}$ cells compared 


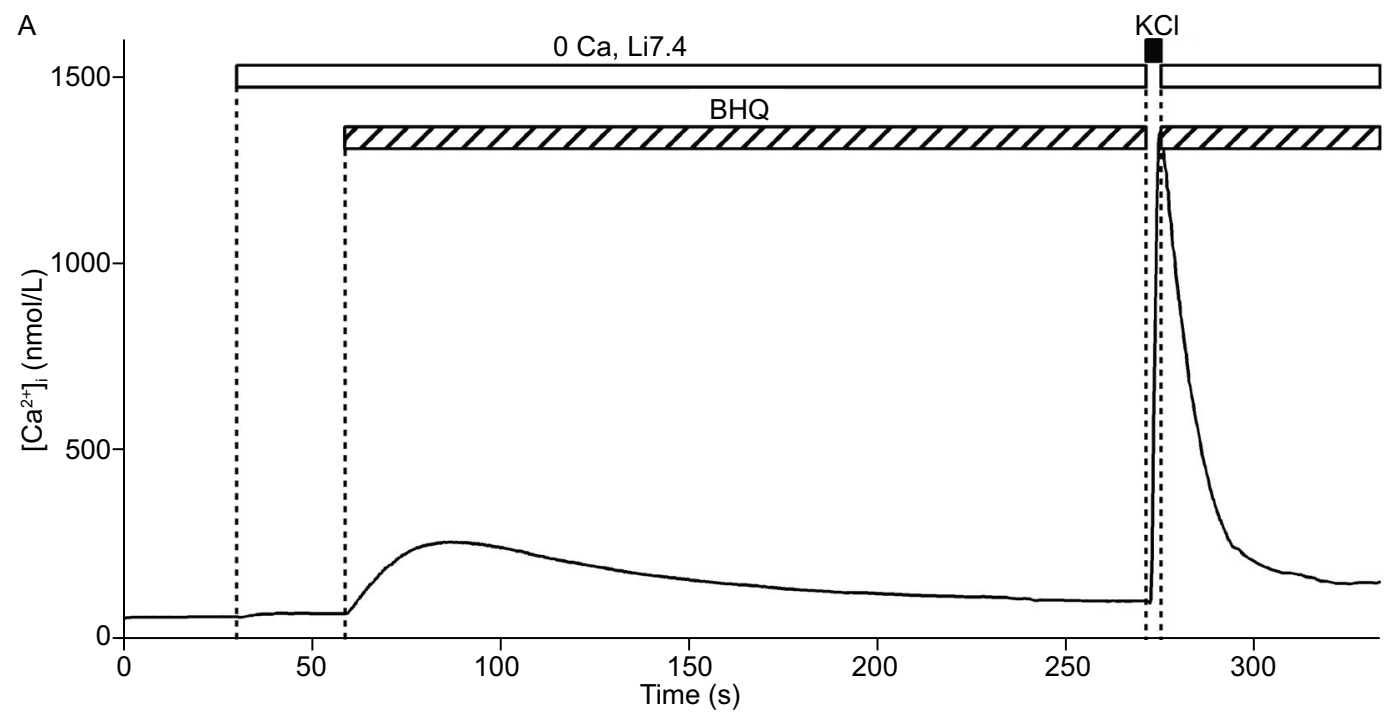

B

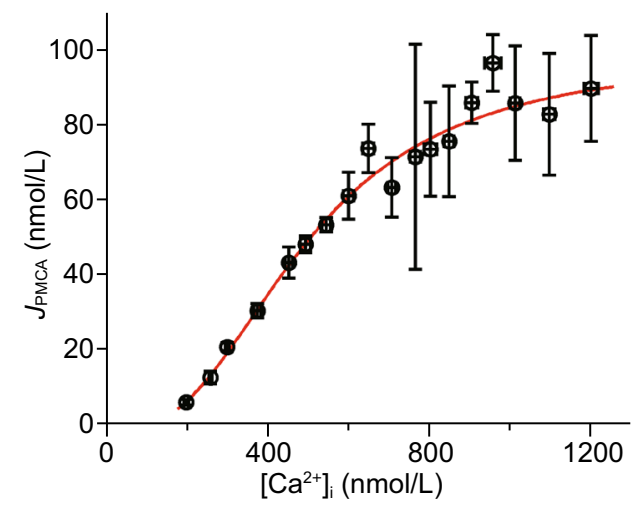

D

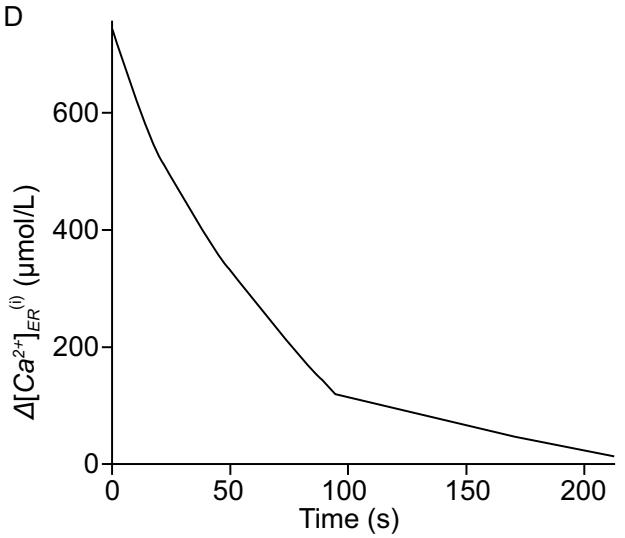

C

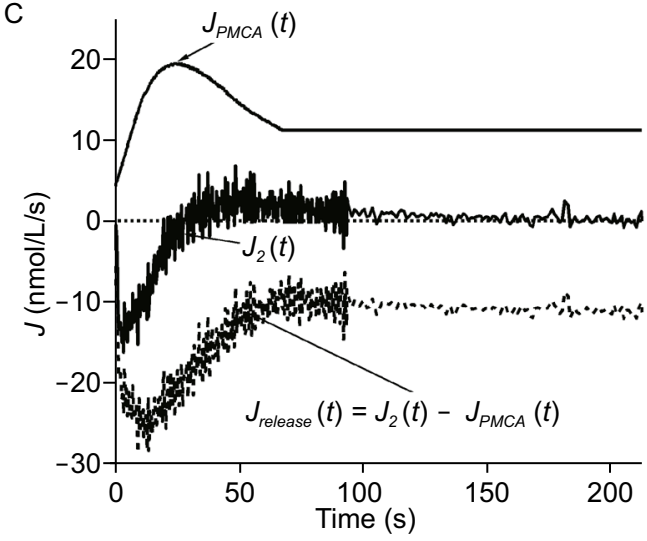

E

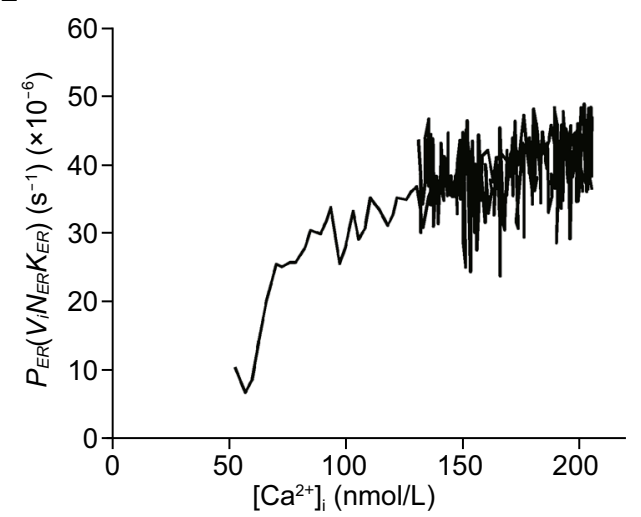

Figure 4. Detection of $\mathrm{Ca}^{2+}$ content in the ER and $\mathrm{ER} \mathrm{Ca}^{2+}$ permeability in single beta-cells. (A) A cell was initially bathed in Ca ${ }^{2+}$ -free and $\mathrm{Na}^{+}$-free solution, then switched to a solution containing $100 \mu \mathrm{mol} / \mathrm{LBHQ}$ to block the SERCA pump. After depletion of the Ca ${ }^{2+}$ in the $\mathrm{ER}, \mathrm{KCl}(70 \mathrm{mmol} / \mathrm{L})$ with $\mathrm{Ca}^{2+}(4 \mathrm{mmol} / \mathrm{L})$ was applied to the cell for $3 \mathrm{~s}$ to induce a transient increase in $\left[\mathrm{Ca}^{2+}\right]_{\mathrm{i}}$. The clearance dynamics thereafter were mainly due to the removal of $\mathrm{Ca}^{2+}$ by the PMCA $\left(J_{P M C A}\right)$. (B) The correlation of $J_{P M C A}$ with $\left[C a^{2+}\right]_{i}$ obtained from (A) can be fitted with a Hill function. (C) Time course of $\mathrm{J}_{\mathrm{PMCA}}$, total cytoplasmic $\mathrm{Ca}^{2+}$ flux $\left(J_{2}\right)$ and $J_{\text {release }}$ after $\mathrm{BHQ}$ application. $J_{\text {release }}$ was calculated as the difference between the $J_{2}$ and the simulated $J_{P M C A}$ at different time points after BHQ application. (D) Plot of time course of $\Delta\left[\mathrm{Ca}^{2+}\right]_{E R}^{(t)}(t)$ after BHQ application, which was calculated as stated in the main text (Albrecht et al. 2002). (E) Relationship of $P_{E R}\left[V_{i} /\left(v_{E R} k_{E R}\right)\right]$ to different $\left[\mathrm{Ca}^{2+}\right]_{i}$ obtained during the $\mathrm{BHQ}$-stimulated ER calcium release. 

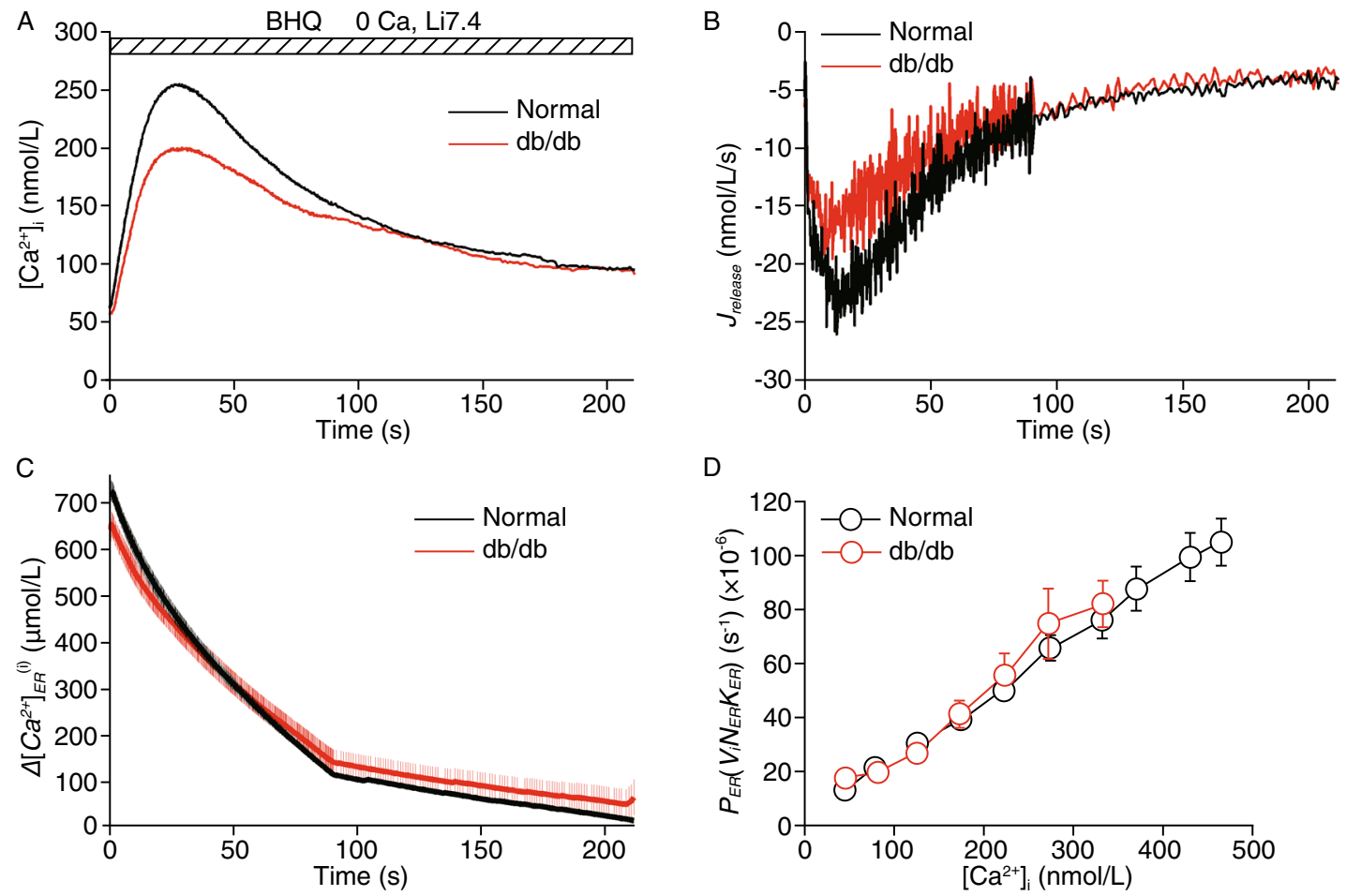

Figure 5. Reduced $\Delta\left[\mathrm{Ca}^{2+}\right]_{E R}^{(i)}$ and unaltered ER $\mathrm{Ca}^{2+}$ permeability in $\mathrm{db} / \mathrm{db}$ beta-cells. (A) Average $\mathrm{BHQ}$-triggered $\left[\mathrm{Ca}{ }^{2+}\right]_{\mathrm{i}}$ transients in $\mathrm{Ca}^{2+}$-free and $\mathrm{Na}^{+}$-free solutions from normal beta-cells $(n=43$, dark) and db/db diabetic beta-cells $(n=31$, red). (B) Time courses of average $J_{\text {release }}$ in normal and $\mathrm{db} / \mathrm{db}$ cells. (C) Reduced initial $\Delta\left[\mathrm{Ca}^{2+}\right]_{E R}^{(i)}$ in $\mathrm{db} / \mathrm{db}$ diabetic beta-cells relative to normal cells $(P<0.05)$. (D) The average relative ER permeability during the BHQ stimulation was approximately the same in normal and $\mathrm{db} / \mathrm{db}$ diabetic beta-cells.

with the control cells. However, the glucose-stimulated $\left[\mathrm{Ca}^{2+}\right]_{i}$ increase was accelerated in the $\mathrm{db} / \mathrm{db}$ cells, and the percentage of time the cells spent over the $\left[\mathrm{Ca}^{2+}\right]_{\mathrm{i}}$ plateau was slightly, but not significantly, different in the $\mathrm{db} / \mathrm{db}$ cells. Overall, our data suggest that multiple characteristics of the glucose-triggered calcium transient are altered in $\mathrm{db} / \mathrm{db}$ beta-cells.

\section{DISCUSSION}

In the current study, we showed that the PMCA activity in islets from $\mathrm{db} / \mathrm{db}$ mice was not significantly different compared with that observed in normal mice, in contrast to the previously reported down-regulation of PMCA function in $\mathrm{db} / \mathrm{db}$ islets and islets with insulin resistance (Roe et al. 1994; Hoenig et al. 1990; Levy et al. 1998; Alzugaray et al. 2009). The difference may be due to the different experimental conditions tested and the different cell models used. However, because PMCA plays a minor role in calcium clearance after depolarization in both mouse and rat pancreatic betacells (Chen et al. 2003; Hughes et al. 2006), we believe that PMCA may not be the primary target in the reshaping of beta-cell calcium signaling pathways during the development of diabetes. The functions of the SERCA2 and SERCA3 subtypes were both impaired in $\mathrm{db} / \mathrm{db}$ beta-cells, as opposed to the selective impairment of SERCA3 function in GK rats. This result partially explains the normoglycemic phenotype of SERCA3 KO mice (Arredouani et al. 2002). Because the high-affinity SERCA2 subtype functions in basal $\left[\mathrm{Ca}^{2+}\right]_{\mathrm{i}}$ regulation in beta-cells (Arredouani et al. 2002), its down-regulation correlates with the reduction in the glucose-stimulated initial decrease in $\left[\mathrm{Ca}^{2+}\right]_{i}$ in $\mathrm{db} / \mathrm{db}$ beta-cells (Fig. 6B), which may perturb glucose-stimulated insulin secretion (Roe et al. 1994; Marie et al. 2001). In addition, we report for the first time a $30 \%$ increase in NCX activity in $\mathrm{db} / \mathrm{db}$ beta-cells, which is consistent with the enhancement of NCX transcription observed in islets cultured in high glucose (Ximenes et al. 2003). Thus our data generally agree with previous studies conducted in this field. In addition, by fitting the experimental data to a modified mathematical model, we obtained a quantitative description of all alterations in the calcium signaling pathways in $\mathrm{db} / \mathrm{db}$ mice, which has not been previously reported.

Perturbed $\mathrm{Ca}^{2+}$ homeostasis has long been proposed as a hallmark of diabetes (Bergsten 2000). Despite the many alterations in the calcium signaling pathway in beta-cells from $\mathrm{db} / \mathrm{db}$ mice, we propose that the down-regulation of SERCA is the earliest event. SERCA2 and SERCA3 expression levels are reduced in islets from both type I and 

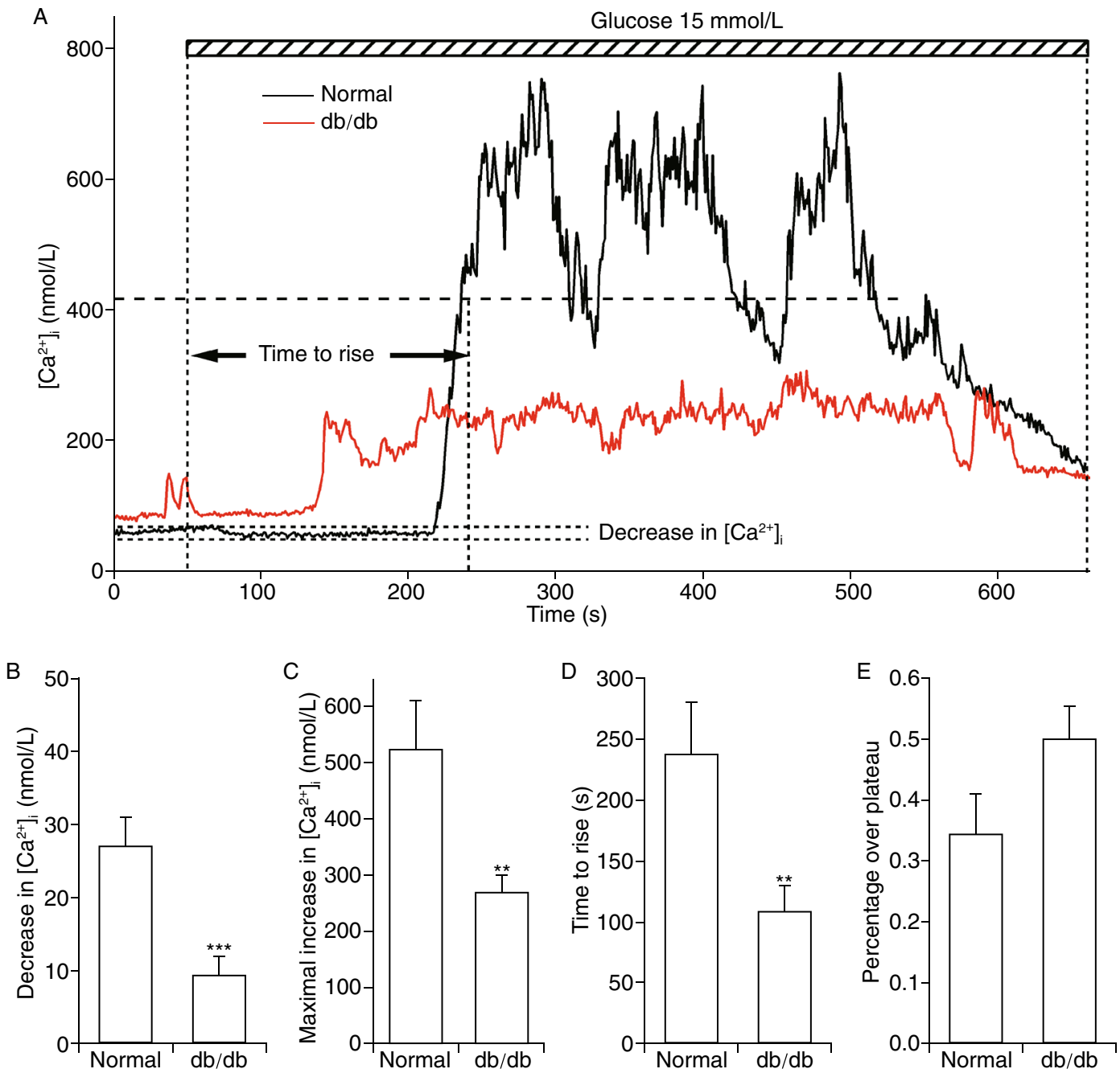

Figure 6. Altered glucose-triggered calcium oscillations in $\mathrm{db} / \mathrm{db}$ beta-cells. (A) Representative examples of calcium oscillations triggered by glucose $(15 \mathrm{mmol} / \mathrm{L})$ in one beta-cell from normal mice (dark) and in one beta-cell from $\mathrm{db} / \mathrm{db} \mathrm{mice}(\mathrm{red})$. The initial decrease in $\left[\mathrm{Ca}^{2+}\right]_{\mathrm{i}}$ was quantified as the difference between the resting $\left[\mathrm{Ca}^{2+}\right]_{\mathrm{i}}$ and the minimal $\left[\mathrm{Ca}^{2+}\right]_{\mathrm{i}}$ reached within $120 \mathrm{~s}$ after glucose perfusion. The maximal increase in $\left[\mathrm{Ca}^{2+}\right]_{i}$ was calculated as the difference between the resting $\left[\mathrm{Ca}^{2+}\right]_{i}$ and the maximal $\left[\mathrm{Ca}^{2+}\right]_{\mathrm{i}}$ reached within the period of glucose perfusion. The time to rise was defined as the time delay between the perfusion of glucose and the time when $\left[\mathrm{Ca}^{2+}\right]_{\mathrm{i}}$ reached $50 \%$ of the maximal increase in $\left[\mathrm{Ca}^{2+}\right]_{i}$. Finally, the percentage over plateau of each trace was defined as the time during which the $\left[\mathrm{Ca}^{2+}\right]_{i}$ was greater than $50 \%$ of the maximal increase divided by the total time of glucose stimulation. (B, C, D, E) Compared to normal cells $(n=23)$, pancreatic beta-cells from $\mathrm{db} / \mathrm{db}$ mice $(n=21)$ exhibited a reduction in the average initial decrease in $\left[\mathrm{Ca}^{2+}\right]_{i}(B)$, a reduction in the average maximal increase in $\left[\mathrm{Ca}^{2+}\right]_{i}(C)$, and an accelerated response to glucose (D). Although $\mathrm{db} / \mathrm{db}$ cells spent a slightly greater percentage of time at $\left[\mathrm{Ca}^{2+}\right]_{i}$ greater than $50 \%$ of the maximal increase in $\left[\mathrm{Ca}^{2+}\right]_{i}$ during glucose stimulation, the average difference compared to normal cells was not significant $(\mathrm{E})$.

type II diabetic mice at earlier stages (Varadi et al. 1996; Liang et al. 2011), which may be due to increased levels of glucose (Levy et al. 1998), saturated fatty acids (Cunha et al. 2008), and cytokines (Dula et al. 2010; Cardozo et al. $2005)$ in the blood vessels and enhanced insulin resistance in beta-cells (Borge et al. 2002). Because the SERCA pump is the dominant clearance mechanism in beta-cells that limits the amplitude of $\left[\mathrm{Ca}^{2+}\right]_{i}$ transients after depolarization, SERCA pump inhibition dramatically enhances depolarization-induced insulin secretion (Chen et al. 2003; Hughes et al. 2006). Therefore, the down-regulation of
SERCA is a beneficial adaptation mechanism that enables beta-cells to secrete more insulin to compensate for the loss of beta-cell mass in type I diabetes or to overcome insulin resistance in type II diabetes. This explanation is supported by the accelerated onset of the glucose-stimulated $\mathrm{Ca}^{2+}$ transient in $\mathrm{db} / \mathrm{db}$ diabetic beta-cells relative to the control cells (Fig. 6B). Along with the reduction in SERCA expression, fine-tuning of the voltage-gated calcium channel currents is needed to generate suitable $\left[\mathrm{Ca}^{2+}\right]_{\mathrm{i}}$ transients that maximize the secretion response and minimize the apoptosis triggered by high $\left[\mathrm{Ca}^{2+}\right]_{i}$. Because 
the NCX contributes more to the total clearance mechanism of beta-cells at relatively high $\left[\mathrm{Ca}^{2+}\right]_{\mathrm{i}}$ (Chen et al. 2003), the loss of low-affinity SERCA3 may lead to the adaptive upregulation of NCX observed here, which assists in calcium clearance from the cytosol during the stimulation and shaping of glucose-triggered calcium transients. Despite the significant reduction in SERCA activity and the enhanced NCX activity, the decrease in $\left[\mathrm{Ca}^{2+}\right]_{\mathrm{ER}}(11 \%)$ in $\mathrm{db} / \mathrm{db}$ betacells was relatively small, in contrast to the severe reduction in $\left[\mathrm{Ca}^{2+}\right]_{E R}$ from insulin-secreting cell lines treated acutely or chronically with saturated fatty acids (Cunha et al. 2008; Gwiazda et al. 2009). These results highlight the importance of systematic investigations of calcium signaling pathways alterations in primary beta-cells isolated from diabetic animals, rather than solely detecting alterations in beta-cells cultured in conditions that mimic diabetes. Decreased $\left[\mathrm{Ca}^{2+}\right]_{\mathrm{ER}}$ is a susceptibility factor for ER stress (Cunha et al. 2008; Cardozo et al. 2005). Therefore, in the long run, a prolonged small decrease in $\left[\mathrm{Ca}^{2+}\right]_{E R}$ in combination with other $\mathrm{ER}$ stress susceptibility factors, such as excessive insulin biosynthesis (Grill and Bjorklund 2001), may ultimately result in beta-cell failure, apoptosis, and severe glucose intolerance.

In conclusion, we characterize changes in multiple aspects of the calcium signaling pathway in beta-cells isolated from $\mathrm{db} / \mathrm{db}$ mice compared with the control. These quantitative studies will help build better models to describe glucose-induced $\mathrm{Ca}^{2+}$ oscillations in diabetic beta-cells (Bertram et al. 2004), which will provide insights into the development of insulin secretion dysfunction and beta-cell failure in the development of diabetes.

\section{MATERIALS AND METHODS}

Cell culture and Western blotting experiments

Primary islets and beta-cells were isolated from age-matched C57BL/6J and $\mathrm{db} / \mathrm{db}$ mice (7-8 weeks) as previously described (Chen et al. 2003). Mouse handling and experimental procedures were conducted in accordance with the Committee for the Use of Live Animals in Teaching and Research at Institute of Molecular Medicine, Peking University. The protocol was approved by the Committee on the Ethics of Animal Experiments of Peking University (Permit Number: IMM-ChenLY-1). All surgery was performed under chloral hydrate anesthesia, and all efforts were made to minimize suffering. At this age, $\mathrm{db} / \mathrm{db}$ mice were overweight and glucose intolerant, as previously reported (Kobayashi et al. 2000). The isolated cells were plated onto polyornithinecoated glass coverslips and cultured at $37^{\circ} \mathrm{C}$ in $5 \% \mathrm{CO}_{2}$ in RPMI 1640 culture medium containing $10 \mathrm{mmol} / \mathrm{L}$ glucose, $10 \%$ fetal bovine serum, $100 \mu \mathrm{g} / \mathrm{mL}$ streptomycin and $100 \mathrm{IU} / \mathrm{mL}$ penicillin. Pancreatic beta-cells were identified by size (Cho et al. 2010) and generally used on culture day 2 or 3 . For the Western blotting experiments (Fig. 2), isolated islets were homogenized using homogenate buffer to obtain total proteins. Equal amounts of proteins (approximately $30 \mu \mathrm{g} / \mathrm{lane}$ ) were loaded to SDS-PAGE and analyzed by Western blotting using anti-SERCA1/2/3 (SANTA
CRUZ, 1:800) and anti-beta actin antibody (Sigma, St. Louis, MO, 1:2000). The incubation with the antibodies was followed by the application of rabbit anti-mouse IgG peroxidase conjugate (Sigma, St. Louis, MO, 1:5000) and goat anti-rabbit lgG (Perkin Elmer, 1:5000). The blots were then probed with Western Lighting plusECL (Perkin Elmer, Inc.) (He et al. 2008).

\section{Experimental set-up and $\mathrm{Ca}^{2+}$ photometry}

Cells were loaded with fura-2-AM $(10 \mu \mathrm{mol} / \mathrm{L})$ in modified Ringer's solution $\left(130 \mathrm{mmol} / \mathrm{L} \mathrm{NaCl}, 2.5 \mathrm{mmol} / \mathrm{L} \mathrm{KCl}, 1 \mathrm{mmol} / \mathrm{L} \mathrm{MgCl}_{2}, 2\right.$ $\mathrm{mmol} / \mathrm{L} \mathrm{CaCl}_{2}, 4 \mathrm{mmol} / \mathrm{L}$ glucose, and $10 \mathrm{mmol} / \mathrm{L}$ HEPES, $\mathrm{pH}$ 7.3) at room temperature for 20-25 min. The modified Ringer's solution was also used as the extracellular solution for basal recording in the glucose-induced calcium oscillation experiments, in which $15 \mathrm{mmol} / \mathrm{L}$ glucose replaced $4 \mathrm{mmol} / \mathrm{L}$ glucose as the stimulus. For the $\mathrm{Ca}^{2+}$ clearance/[Ca $\left.{ }^{2+}\right]_{E R}$ evaluation experiment, the cells were perfused with the modified Ringer's solution containing $15 \mathrm{mmol} / \mathrm{L}$ (instead of $4 \mathrm{mmol} / \mathrm{L}$ ) glucose and $250 \mu \mathrm{mol} / \mathrm{L}$ diazoxide, and various reagents were added to this solution to inhibit clearance mechanisms, as described in the individual experiments. The depolarization solution $(\mathrm{KCl})$ consisted of $70 \mathrm{mmol} / \mathrm{L} \mathrm{KCl}, 67 \mathrm{mmol} / \mathrm{L} \mathrm{NaCl}, 4 \mathrm{mmol} / \mathrm{L} \mathrm{CaCl}_{2}$, $1 \mathrm{mmol} / \mathrm{L} \mathrm{MgCl} 2,15 \mathrm{mmol} / \mathrm{L}$ glucose, $250 \mu \mathrm{mol} / \mathrm{L}$ diazoxide, and 10 $\mathrm{mmol} / \mathrm{L}$ HEPES, $\mathrm{pH}$ 7.3. To inhibit the NCX, we used a $\mathrm{Na}^{+}$-free solution in which $\mathrm{Li}^{+}$replaced $\mathrm{Na}^{+}$( $\left.\mathrm{Li7.4}\right)$ and raised the $\mathrm{pH}$ of the solution to 8.8 ( $\mathrm{Na8.8}$ ) to slow the PMCA pump (Chen et al. 2003). Rapid solution changes ( $<500 \mathrm{~ms}$ ) were digitally controlled by a fast local perfusion system (Chen et al. 2003).

For photometry, the cells were excited by sequential 340 and $380 \mathrm{~nm}$ light generated by a computer-controlled PolyChrome IV (TILL Photonics) light source, and the emission at $505 \mathrm{~nm}$ was collected by a photodiode. The PULSE software was used to coordinate protocols and collect data, which were analyzed using IGOR Pro. The standard calibration parameters $R_{\min }, R_{\max }$ and $K^{*}$ were determined as previously described (Chen et al. 2003).

Measurement of $\mathrm{J}_{\text {SERCA }}$ and $\mathrm{J}_{\text {release }}$ activity at different $\left[\mathrm{Ca}^{2+}\right]_{i}$ in live beta-cells

Following previously published reports (Duman et al. 2006; Albrecht et al. 2002), we applied a high dose of tert-butylhydroquinone (BHQ, $100 \mu \mathrm{mol} / \mathrm{L}$ ) to abruptly stop the uptake of $\mathrm{Ca}^{2+}$ by the ER via the SERCA pump. The total cellular $\mathrm{Ca}^{2+}$ flux can be calculated as the rate of change of $\left[\mathrm{Ca}^{2+}\right]_{\mathrm{i}}$ (defined as $-\mathrm{d}\left[\mathrm{Ca}^{2+}\right]_{\mathrm{i}} / \mathrm{dt}$ ). Prior to the application of $\mathrm{BHQ}$, the total cellular $\mathrm{Ca}^{2+}$ flux $\left(J_{1}\right)$ can be described by the equation

$J_{1}=J_{S E R C A}+J_{\text {release }}+J_{P M}$

$J_{S E R C A}$ is the $\mathrm{Ca}^{2+}$ flux due to the $\mathrm{BHQ}$-sensitive pumping of $\mathrm{Ca}^{2+}$ into the ER; $J_{\text {release }}$ is the flux into the cytosol from intracellular stores; and $J_{P M}$ is the flux across the plasma membrane. The acute application of $\mathrm{BHQ}$ changes the new total cellular $\mathrm{Ca}^{2+}$ flux $\left(J_{1}\right)$ according to

$J_{2}=J_{\text {release }}+J_{P M}$

Therefore, the value of $J_{S E R C A}$ was calculated as the difference between $J_{1}$ and $J_{2}$. In Fig. 4 , we briefly treated the beta-cells with High $\mathrm{K}^{+}$solution containing $\mathrm{BHQ}$ to obtain $\mathrm{Ca}^{2+}$ clearance by the 
PMCA pump alone, and $J_{P M C A}$ was fitted to a Hill equation to describe its relationship to different $\left[\mathrm{Ca}^{2+}\right]_{i}$ levels. Therefore, a different $J_{\text {release }}(t)$ was calculated based on Eq. 2, and the appropriate value of $J_{P M C A}$ was inserted.

\section{Data analysis}

All data were analyzed using the Igor Pro software (Wavemetrics, Lake Oswego, OR). The averaged results are presented as the mean value \pm SEM of the number of experiments indicated. The statistical significance was evaluated using either Student's $t$-test for single Gaussian distributed datasets or the Mann-Whitney rank sum test for non-single Gaussian-distributed datasets. The asterisks * , ${ }^{* *}$, and ${ }^{* * *}$ denote statistical significances with $P$ values less than 0.05 , 0.01 , and 0.001 , respectively.

\section{ACKNOWLEDGEMENTS}

The work was supported by grants from the National Basic Research Program (973 Program) (No. 2013CB531200), the National Key Technology R\&D Program (No. SQ2011SF11B01041), National Natural Science Foundation of China (Grant Nos. 31221002 and 81222020), the Beijing Natural Science Foundation (Nos. 7121008 and 7142071), the Basic and Clinical Research Fund of Capital Medical University (No. 13JL19) and the Talents Project of Department of Beijing Municipal Party Committee Organization of the Communist Party of China (No. 2011D005018000004). This work is also supported by the grant GM83913 from the U.S. National Institutes of Health.

\section{COMPLIANCE WITH ETHICS GUIDELINES}

Kuo Liang, Wen Du, Jingze Lu, Fei Li, Lu Yang, Yanhong Xue, Bertil Hille and Liangyi Chen declare that they have no conflict of interest.

All animal experimental procedures were conducted in accordance with the Committee for the Use of Live Animals in Teaching and Research at Institute of Molecular Medicine, Peking University.

\section{OPEN ACCESS}

This article is distributed under the terms of the Creative Commons Attribution License which permits any use, distribution, and reproduction in any medium, provided the original author(s) and the source are credited.

\section{REFERENCES}

Albrecht MA, Colegrove SL, Friel DD (2002) Differential regulation of $\mathrm{ER} \mathrm{Ca}^{2+}$ uptake and release rates accounts for multiple modes of $\mathrm{Ca}^{2+}$-induced $\mathrm{Ca}^{2+}$ release. J Gen Physiol 119:211-233

Alzugaray ME, Garcia ME, Del Zotto HH, Raschia MA, Palomeque J et al (2009) Changes in islet plasma membrane calcium-ATPase activity and isoform expression induced by insulin resistance. Arch Biochem Biophys 490:17-23

Arredouani A, Guiot Y, Jonas JC, Liu LH, Nenquin M et al (2002) SERCA3 ablation does not impair insulin secretion but suggests distinct roles of different sarcoendoplasmic reticulum $\mathrm{Ca}^{(2+)}$ pumps for $\mathrm{Ca}^{(2+)}$ homeostasis in pancreatic beta-cells. Diabetes 51:3245-3253
Bergsten P (2000) Pathophysiology of impaired pulsatile insulin release. Diabetes Metab Res Rev 16:179-191

Bertram R, Satin L, Zhang M, Smolen P, Sherman A (2004) Calcium and glycolysis mediate multiple bursting modes in pancreatic islets. Biophys J 87:3074-3087

Borge PD, Moibi J, Greene SR, Trucco M, Young RA et al (2002) Insulin receptor signaling and sarco/endoplasmic reticulum calcium ATPase in beta-cells. Diabetes 51(Suppl 3):S427-S433

Cardozo AK, Ortis F, Storling J, Feng YM, Rasschaert J et al (2005) Cytokines downregulate the sarcoendoplasmic reticulum pump $\mathrm{Ca}^{2+}$ ATPase $2 \mathrm{~b}$ and deplete endoplasmic reticulum $\mathrm{Ca}^{2+}$, leading to induction of endoplasmic reticulum stress in pancreatic beta-cells. Diabetes 54:452-461

Chen LY, Koh DS, Hille B (2003) Dynamics of calcium clearance in mouse pancreatic beta-cells. Diabetes 52:1723-1731

Cho JH, Chen L, Kim MH, Chow RH, Hille B et al (2010) Characteristics and functions of \{alpha\}-amino-3-hydroxy-5methyl-4-isoxazolepropionate receptors expressed in mouse pancreatic \{alpha\}-cells. Endocrinology 151:1541-1550

Cunha DA, Hekerman P, Ladriere L, Bazarra-Castro A, Ortis F et al (2008) Initiation and execution of lipotoxic ER stress in pancreatic beta-cells. J Cell Sci 121:2308-2318

Dula SB, Jecmenica M, Wu R, Jahanshahi P, Verrilli GM et al (2010) Evidence that low-grade systemic inflammation can induce islet dysfunction as measured by impaired calcium handling. Cell Calcium 48:133-142

Duman JG, Chen LY, Palmer AE, Hille B (2006) Contributions of intracellular compartments to calcium dynamics: implicating an acidic store. Traffic 7:859-872

Grill V, Bjorklund A (2001) Overstimulation and beta-cell function. Diabetes 50(Suppl 1):S122-S124

Gwiazda KS, Yang TL, Lin Y, Johnson JD (2009) Effects of palmitate on ER and cytosolic $\mathrm{Ca}^{2+}$ homeostasis in beta-cells. Am J Physiol Endocrinol Metab 296:E690-E701

He ZX, Fan JM, Kang LJ, Lu JZ, Xue YH et al (2008) $\mathrm{Ca}^{2+}$ triggers a novel clathrin-independent but actin-dependent fast endocytosis in pancreatic beta cells. Traffic 9:910-923

Hoenig M, Lee RJ, Ferguson DC (1990) Glucose inhibits the highaffinity $\left(\mathrm{Ca}^{2+}+\mathrm{Mg}^{2+}\right)$-ATPase in the plasma membrane of a glucoseresponsive insulinoma. Biochim Biophys Acta 1022:333-338

Hughes E, Lee AK, Tse A (2006) Dominant role of sarcoendoplasmic reticulum $\mathrm{Ca}^{2+}$-ATPase pump in $\mathrm{Ca}^{2+}$ homeostasis and exocytosis in rat pancreatic beta-cells. Endocrinology 147:1396-1407

Islam MS (2002) The ryanodine receptor calcium channel of betacells: molecular regulation and physiological significance. Diabetes 51:1299-1309

Iwashima Y, Abiko A, Ushikubi F, Hata A, Kaku K et al (2001) Downregulation of the voltage-dependent calcium channel (VDCC) beta-subunit mRNAs in pancreatic islets of type 2 diabetic rats. Biochem Biophys Res Commun 280:923-932

Kato S, Ishida H, Tsuura Y, Okamoto Y, Tsuji K et al (1994) Increased calcium-channel currents of pancreatic beta cells in neonatally streptozocin-induced diabetic rats. Metabolism 43:1395-1400

Kato S, Ishida H, Tsuura Y, Tsuji K, Nishimura M et al (1996) Alterations in basal and glucose-stimulated voltage-dependent $\mathrm{Ca}^{2+}$ channel activities in pancreatic beta cells of non-insulindependent diabetes mellitus GK rats. J Clin Invest 97:2417-2425 
Kobayashi K, Forte TM, Taniguchi S, Ishida BY, Oka K et al (2000) The $\mathrm{db} / \mathrm{db}$ mouse, a model for diabetic dyslipidemia: molecular characterization and effects of Western diet feeding. Metabolism 49:22-31

Levy J, Zhu Z, Dunbar JC (1998) The effect of glucose and calcium on $\mathrm{Ca}^{2+}$-adenosine triphosphatase in pancreatic islets isolated from a normal and a non-insulin-dependent diabetes mellitus rat model. Metabolism 47:185-189

Liang K, Du W, Zhu W, Liu S, Cui Y et al (2011) Contribution of different mechanisms to pancreatic beta-cell hyper-secretion in non-obese diabetic (NOD) mice during pre-diabetes. J Biol Chem 286:39537-39545

Lytton J, Westlin M, Burk SE, Shull GE, MacLennan DH (1992) Functional comparisons between isoforms of the sarcoplasmic or endoplasmic reticulum family of calcium pumps. J Biol Chem 267:14483-14489

Marie JC, Bailbe D, Gylfe E, Portha B (2001) Defective glucosedependent cytosolic $\mathrm{Ca}^{2+}$ handling in islets of GK and $\mathrm{nSTZ}$ rat models of type 2 diabetes. J Endocrinol 169:169-176

Roe MW, Philipson LH, Frangakis CJ, Kuznetsov A, Mertz RJ et al (1994) Defective glucose-dependent endoplasmic reticulum $\mathrm{Ca}^{2+}$ sequestration in diabetic mouse islets of Langerhans. J Biol Chem 269:18279-18282

Roe MW, Worley JF 3rd, Tokuyama Y, Philipson LH, Sturis J et al (1996) NIDDM is associated with loss of pancreatic beta-cell L-type $\mathrm{Ca}^{2+}$ channel activity. Am J Physiol 270:E133-E140

Rorsman P (1997) The pancreatic beta-cell as a fuel sensor: an electrophysiologist's viewpoint. Diabetologia 40:487-495

Varadi A, Molnar E, Ostenson CG, Ashcroft SJ (1996) Isoforms of endoplasmic reticulum $\mathrm{Ca}(2+)$-ATPase are differentially expressed in normal and diabetic islets of Langerhans. Biochem J 319(Pt 2): 521-527

Varadi A, Lebel L, Hashim Y, Mehta Z, Ashcroft SJ et al (1999) Sequence variants of the sarco(endo)plasmic reticulum $\mathrm{Ca}^{(2}$ ${ }^{+}$-transport ATPase 3 gene (SERCA3) in Caucasian type II diabetic patients (UK Prospective Diabetes Study 48). Diabetologia 42:1240-1243

Ximenes HM, Kamagate A, Van Eylen F, Carpinelli A, HerchuelzA (2003) Opposite effects of glucose on plasma membrane $\mathrm{Ca}^{2+}$-ATPase and $\mathrm{Na} / \mathrm{Ca}$ exchanger transcription, expression, and activity in rat pancreatic beta-cells. J Biol Chem 278:22956-22963 